\title{
Poziom wypalenia zawodowego wśród pielęgniarek pracujących w szpitalu
}

\author{
The level of occupational burnout among nurses working in a hospital
}

\author{
WIOLETTA WOJCIECHOWSKA ${ }^{1}$, BEATA MAŁECKA ${ }^{1}$, \\ BEATA FRĄCKOWIAK ${ }^{1}$
}

1 Instytut Nauk o Zdrowiu Kujawska Szkoła Wyższa we Włocławku

\section{Streszczenie}

Wstęp. Występowanie zjawiska wypalenia zawodowego ma charakter wielowymiarowy i dotyczy różnych grup zawodowych i specjalności. Pielęgniarki to grupa zawodowa szczególnie zagrożona wypaleniem zawodowym, które wiąże się ze specyficznymi obciążeniami typowymi dla tego zawodu. Obciążenia te niosą za sobą duży potencjał negatywnych oddziaływań na psychiczną i fizyczną sferę funkcjonowania personelu pielęgniarskiego.

Cel. Celem pracy była ocena poziomu wypalenia zawodowego pielęgniarek pracujących na różnych oddziałach szpitalnych.

Materiał i metoda. Badaniami objęto 150 osobową grupę pielęgniarek pracujących w szpitalu w okresie od 6.01.2020 roku do 10.03.2020 roku. W badaniach posłużono się kwestionariuszem ankiety własnej liczącym 21 pytań i Kwestionariuszem Wypalenia Zawodowego MBI Ch. Maslach.

Wyniki. Analiza statystyczna nie wykazała istotnej zależności pomiędzy miejscem pracy ankietowanych a ich poziomem wypalenia zawodowego $\mathrm{w}$ depersonalizacji. Poziom wypalenia w podskali poczucia osiągnięć osobistych u wszystkich pielęgniarek/pielęgniarzy kształtował się na średnim poziomie. Specyfika oddziału i specyficzne dla niej problemy nie miały istotnego wpływu na poziom wypalenia. Poziom wypalenia wzrastał wraz z wiekiem i stażem pracy, ale wśród początkujących pielęgniarek widoczne były objawy wypalenia zawodowego. Większość badanych pielęgniarek/pielęgniarzy uważała swoją pracę za stresującą, co miało duży wpływ na występowanie wypalenia zawodowego. Głównym determinantem stresu były dla nich przepracowanie 
oraz nieadekwatne do pracy wynagradzanie. Badania nie wykazały istotnego wpływu „ciężkości” oddziału, na którym pracowali respondenci jako czynnika determinującego stres. Pielęgniarki/pielęgniarze byli często przepracowani, doświadczali silnego stresu, mimo to cechowali się ogromnym przywiązaniem do zawodu i nie deklarowali chęci jego zmiany.

Wnioski. Przeprowadzone badania wykazały, że pielęgniarki pracujące w szpitalu należały do grupy o średnim poziomie wypalenia zawodowego. Wśród badanych dominowały objawy emocjonalnego wyczerpania, szczególnie u pielęgniarek pracujących w oddziałach o dużym stopniu ciężkości.

Słowa kluczowe: pielęgniarstwo, wypalenie zawodowe, stres

\section{Summary}

Introduction. The occurrence of the phenomenon of occupational burnout is multidimensional and concerns various professional groups and specialties. Nurses are a professional group particularly at risk of burnout, which is associated with specific burdens typical for this profession. These burdens carry a high potential for negative impacts on the mental and physical sphere of functioning of the nursing staff.

Aim. The aim of the study was to assess the level of occupational burnout of nurses working in various hospital departments.

Material and methods. The study included a group of 150 nurses working in the hospital in the period from January 6, 2020 to March 10, 2020. The study used a self-questionnaire consisting of 21 questions and the MBI Ch. Maslach.

Results. Statistical analysis did not show a significant relationship between the respondents' workplace and their level of occupational burnout in depersonalization. The level of burnout in the subscale of sense of personal achievement in all nurses is average. The specifics of the ward and its specific problems do not significantly affect the level of burnout. The level of burnout increases with age and seniority, but symptoms of burnout are already visible among novice nurses. Most of the surveyed nurses consider their work stressful, which has a large impact on the occurrence of occupational burnout. The main determinant of stress for them is overwork and inadequate remuneration for work. The research did not show a significant influence of the "heaviness" of the department where the respondents worked as a factor determining stress. Nurses are 
often overworked, experience strong stress, yet they are highly attached to the profession and do not declare the will to change it.

Conclusions. The conducted research has shown that the nurses working hospital belong to the group with an average level of occupational burnout. Symptoms of emotional exhaustion dominate among the respondents, especially among nurses working in departments with a high degree of severity.

Keywords: nursing, burnout, stress

\section{Wstęp}

Problem wypalenia zawodowego to zjawisko szeroko występujące wśród pracowników systemu ochrony zdrowia. Ważne znaczenie wpływu na syndrom wypalenia zawodowego pielęgniarek ma specyfika obszaru, w którym pracują. Nie chodzi tylko o sam kontakt z osobami chorymi, ale przede wszystkim o charakterystyczny rodzaj problemów z jakimi się spotyka. Każdy z obszarów działalności medycznej stawia przed personelem określone zadania i często wymaga rozwiązywania pojawiających się trudności i przeszkód. Pielęgniarki, jako grupa zawodowa, która wykonując określone zadania angażuje własną osobowość na równi z umiejętnościami profesjonalnymi, są szczególnie narażone na ten syndrom. Ważnym czynnikiem różniącym osoby pracujące w zawodach wiążących się z intensywnym kontaktem z innymi ludźmi, są specyficzne problemy, które przedstawiciele tych profesji rozwiązują - specyfika oddziału szpitalnego związana z typem schorzeń, a także specyficzne wymagania roli, którą podjęli się wykonywać. W przypadku zawodu pielęgniarki podkreśla się takie cechy, jak: codzienny kontakt z chorobą, wymóg stałej czujności, konieczność kontaktu z różnymi osobami zaangażowanymi w ten sam problem, niepewność roli, niska możliwość kontrolowania otoczenia, zhierarchizowany układ zależności zawodowej. Tak sformułowane wymagania zawodowe pielęgniarki warunkują strukturę syndromu wypalenia zawodowego. Wpływają także na skutki subiektywne i obiektywne tego zjawiska, a także ograniczają wybór sposobów radzenia sobie z nim [1]. 
Wykonując pracę zawodową pielęgniarki napotykają na wiele specyficznych wymagań oraz wiele obciążeń. Obciążenie psychiczne wiąże się z ogromną rolą, jaką pełni pielęgniarka w pracy, a którą jest odpowiedzialność. Obciążenie psychiczne w pracy pielęgniarki jest związane z koniecznością stałej koncentracji uwagi, systematycznej obserwacji, szybkiej oceny i reakcji na zmiany w stanie zdrowia pacjentów, z licznymi często natychmiastowymi decyzjami, koniecznością gromadzenia i przekazywania informacji o pacjentach, a także w wielu wypadkach niemożnością przyniesienia ulgi $\mathrm{w}$ cierpieniu, nie tylko $\mathrm{w}$ wymiarze fizycznym ale również psychicznym i duchowym. Stała troska o drugiego człowieka, to często powtarzające się pobudzenie emocjonalne o znacznej sile, doznanie wybitnie stresowe. Pielęgniarki posiadają silnie rozwinięty mechanizm kontroli o cechach unikania, który wzmaga stres i bezpośrednio wpływa na wypalenie zawodowe. Unikanie wzmaga emocjonalne wyczerpanie, które spowodowane jest bezpośrednio przez obciążenie stresowe rolą zawodową i warunkami pracy [2].

\section{Cel}

Celem badań była ocena poziomu wypalenia zawodowego wśród pielęgniarek pracujących w oddziałach szpitalnych.

\section{Materiał i metody}

Badania przeprowadzono w grupie 150 pielęgniarek pracujących w szpitalu na terenie Województwa Kujawsko-Pomorskiego. Na przeprowadzenie badań uzyskano zgodę Komisji Bioetycznej. Udział w badaniach był dobrowolny i anonimowy. Materiał badawczy pozyskano metodą sondażu diagnostycznego przy zastosowaniu ankiety autorskiej oraz Kwestionariusza Wypalenia Zawodowego MBI. Badaniami objęto pielęgniarki i pielęgniarzy z 9 oddziałów: 3 oddziałów zabiegowych - okulistyczny, chirurgia ogólna, chirurgia dziecięca i 6 leczących zachowawczo - oddział wewnętrzny, onkologia, nefrologia ze stacją dializ, neurologia, pediatria i oddział leczenia uzależnień. Wszystkie obliczenia wykonano za pomocą pakietu statystycznego SPSS Statistics 
21,0. Do zbadania zależności statystycznej pomiędzy analizowanymi cechami użyto testu chi kwadrat. Uzyskane wyniki badań poddano analizie statystycznej testem $\chi^{2}$ dla prób niezależnych. Przyjęto 5\% ryzyka błędu wnioskowania. Wartość prawdopodobieństwa p<0,05 uznano za statystycznie istotną.

\section{Wyniki}

Wśród badanych najliczniej reprezentowaną grupą były pielęgniarki powyżej 50 roku życia (61,3\%), natomiast najmniejszą grupę stanowiły pielęgniarki/pielęgniarze w przedziale wiekowym $20-30$ lat (3,3\%). Przedział wiekowy 31-40 lat to 7,3\% badanych, a w przedziale 41-50 lat znalazło się 28\% badanych. Średnia wieku to 56 lat. Wśród badanych grupa kobiet stanowiła 96,7\%, zaś mężczyzn 3,3\%. Średni personel medyczny w większości stanowiły kobiety. Większość badanych $(58,7 \%)$ mieszkała w mieście, na wsi $41,3 \%$. Aż $64 \%$ badanych posiadało wykształcenie średnie zawodowe, 30,7\% wyższe pielęgniarskie, a 5,4\% wykształcenie średnie zawodowe i inne wyższe. Badani ze średnim wykształceniem stanowili większość badanej grupy. Staż pracy badanych podzielono na okresy 10-letnie. Najkrótszy staż pracy wyniósł 5 miesięcy, a najdłuższy 45 lat. Najliczniejszą grupę $(49,3 \%)$ stanowili badani ze stażem pracy 31-40 lat. Badani ze stażem pracy 0-10 lat stanowili 9,3\%, ze stażem 11-20 lat stanowili 13,3\%, a 21,3\% stanowili badani ze stażem 21-30 lat. Wśród badanych były również osoby ze stażem $>40$ lat $(6,7 \%)$. Udział w badaniu wzięło 31 pielęgniarek pracujących w oddziale wewnętrznym, $20 \mathrm{w}$ oddziale neurologii, po 10 pracujących w oddziałach dziecięcym i leczenia uzależnień, po 12 pielęgniarek pracujących w oddziale onkologii i nefrologii ze stacją dializ, oraz 27 pielęgniarek pracujących w oddziale chirurgii i po $14 \mathrm{w}$ oddziałach okulistycznym i chirurgii dziecięcej. Badaną grupę w większości stanowili pracujący w systemie dwuzmianowym $(79,3 \%)$, natomiast $20,7 \%$ badanych pracowało w systemie jednozmianowym. Połowa badanych $(50,7 \%)$ miała zbyt mało czasu na odpoczynek w czasie pełnienia dyżuru, natomiast $45,3 \%$ pielęgniarek/pielęgniarzy nie 
znajdowała na to czasu. $4 \%$ badanych nie odpoczywała z powodu braku przeznaczonego na ten cel miejsca. Zdecydowana większość badanych (88 osób) zadeklarowała, że po dyżurze nocnym spała tylko 2 -3 godziny, zaś 11 badanych nie regenerowała swych sił i spędzała dzień jak każdy inny, co mogło skutkować u nich niedoborem snu. Tylko 25 badanych po dyżurze odsypiała nocną zmianę. Najczęstszą formą spędzania czasu wolnego było wykonywanie prac domowych (120 osób). Część badanych (45) preferowała w czasie wolnym pracę na działce oraz zajmowała się dziećmi lub wnukami (40 badanych). Czas wolny badani spędzali również na oglądaniu telewizji (31 osób), czy w towarzystwie przyjaciół (32 osoby). Tylko 10 badanych w wolnym czasie uprawiała sport. Prawie połowa badanych $(45,3 \%)$ urlopy wypoczynkowe przeznaczała na odpoczynek wyjeżdżając na wczasy. Kolejna połowa badanych na czas urlopu pozostawała w domu, ale $34 \% \mathrm{z}$ nich odpoczywała aktywnie: jeździła na rowerze, spędzała czas nad jeziorem, spacerowała. Tylko 20,7\% przeznaczała swój urlop na porządki domowe, nadrobienie zaległości, pracę na działce. Wśród badanych $37,3 \%$ każdego roku wyjeżdżała na wczasy. Duża grupa pielęgniarek i pielęgniarzy wyjeżdżała na wczasy co drugi rok (24\%), a sporadycznie robiło to $28,7 \%$ badanych. Znikoma liczba badanych (10\%) nie wyjeżdżała na wczasy. Ponad połowa $58 \%$ badanych, podejmowała działania mające na celu poprawę własnego wyglądu: wizyty u kosmetyczki, fryzjera; 38,7\% prowadziła zdrowy styl życia - zdrowo się odżywiała, odpoczywała, relaksowała się; $5 \%$ respondentów uprawiała sport dla poprawy swojej kondycji. Największa grupa badanych $(33,3 \%)$ miała dla siebie dziennie tylko 1-2 godziny, bądź 30 min.; do godziny (28\%). Badani, którzy deklarowali, że nie mieli dla siebie czasu stanowili 8,7\%, zaś $16,7 \%$ badanych poświęcało dla siebie 3-4 godziny w ciągu dnia, a nawet 5-6 godzin (8\%). 55 badanych uważała, że swój czas planuje od czasu do czasu, 36 z nich planuje czasami, 29 osób prawie zawsze ma zaplanowany czas. Natomiast 20 badanych rzadko planowało swój czas, zaś 10 prawie nigdy. 40,7\% średniego personelu medycznego uważała, że raczej radzi sobie ze stresem, natomiast zdecydowanie radzi sobie 
$12,7 \%$ pielęgniarek i pielęgniarzy. 33,3\% badanych nie była pewna, czy potrafi radzić sobie ze stresem, $12 \%$ raczej nie radziła sobie w takich sytuacjach a $0,7 \%$ zdecydowanie tego nie potrafiła. Badani będąc w sytuacji stresowej próbowali znaleźć rozsądne rozwiązanie (90osób), 41 badanych poszukiwało wsparcia, rady, rozmowy. Byli tacy, którzy rekompensowali stres aktywnością fizyczną: sprzątaniem, ćwiczeniami, spacerem (31 osób). Były też takie osoby, które twierdziły, że stres powodował zdenerwowanie (6 osób), a nawet sięgali po używki: alkohol, papierosy (3). Główną przyczyną stresu badanych pielęgniarek było przepracowanie (108 osób), na drugim miejscu badani podawali brak środków finansowych (23 osoby). Przyczyną stresu bywały również konflikty w pracy (16 badanych), trudności w kontaktach z pacjentem (10), czy też trudności w kontaktach z innymi współpracownikami (8 osób). W niwelowaniu stresu dla 67 badanych pomocne było wsparcie rodziny, zaś dla 58 osób rozmowa. Inne formy pozbycia się stresu według badanych to słuchanie muzyki (36 osób), zakupy (22 osoby). 25 badanych osób podawało, że to przyjaciele byli pomocni w sytuacjach stresowych. 12,7\% badanych pielęgniarek /pielęgniarzy uważało, że ich praca jest zawsze stresująca, natomiast największa grupa 35,3\% twierdziła, że praca pielęgniarki jest stresująca od czasu do czasu. $26 \%$ badanych postrzegała pracę pielęgniarki jako często stresującą a $21,3 \%$ jako rzadko stresującą. Znikoma liczba badanych $(4,7 \%)$ nie widziała nic stresującego $\mathrm{w}$ wykonywanej pracy. W zakresie zmiany zawodu $38 \%$ badanych odpowiedziało, że prawie nigdy o tym nie myślało, $26,7 \%$, że rzadko, a $20 \%$, że od czasu do czasu, a tylko 9,3\% pielęgniarek podawało, że często myślało o zmianie zawodu. 
Tabela 1. Minimalne, średnie i maksymalne wyniki badań w poszczególnych podskalach.

\begin{tabular}{|l|c|c|c|c|c|c|}
\hline \multicolumn{5}{|c|}{ Skala z poszczególnych elementów wypalenia zawodowego } \\
\hline & \multicolumn{2}{|c|}{$\begin{array}{c}\text { Liczba uzyskanych } \\
\text { punktów }\end{array}$} & \multicolumn{3}{c|}{ Liczba w \% } \\
\cline { 2 - 7 } & Min & Średnia & Max & $\begin{array}{c}\text { Poziom } \\
\text { niski }\end{array}$ & $\begin{array}{c}\text { Poziom } \\
\text { średni. }\end{array}$ & $\begin{array}{c}\text { Poziom } \\
\text { wysoki }\end{array}$ \\
\hline $\begin{array}{l}\text { Skala wyczerpania } \\
\text { emocjonalnego }\end{array}$ & 8 & 23,6267 & 48 & 28,7 & 64 & 7,3 \\
\hline $\begin{array}{l}\text { Skala braku poczucia } \\
\text { osiągnięć / osobistego } \\
\text { zaangażowania }\end{array}$ & 5 & 23,6867 & 48 & 7,3 & 72,7 & 20 \\
\hline Skala depersonalizacji & 4 & 12,8467 & 30 & 29,3 & 64,7 & 6 \\
\hline
\end{tabular}

Źródło: Opracowanie własne na podstawie badań własnych.

W skali wyczerpania emocjonalnego, średni wynik to 23,62 punktów (min 8, max 48). W podskali depersonalizacji badani uzyskali niski wynik, średnia to 12,84 punktów (min.4, max. 30). Oceniając skalę braku poczucia osiągnięć/osobistego zaangażowania, średnia to 23,68 punktów (min. 5, max. 48).

Badana grupa uzyskała średni poziom wypalenia we wszystkich podskalach: wyczerpania emocjonalnego, depersonalizacji, a także w braku poczucia osiągnięć osobistych. Ogólny poziom wypalenia zawodowego dla badanej grupy wyniósł 20,05 punktów i mieścił się w przedziale średnich wyników. Niski poziom wyczerpania emocjonalnego wykazało 43 badanych, co dało 28,7\%. Średni poziom wyczerpania emocjonalnego wykazało 96 osób - 64\% badanych. Wysoki poziom wyczerpania emocjonalnego wykazało $7,3 \%$ badanych, czyli zaledwie 7 osób. W podskali braku poczucia osiągnięć 109 badanych (72,7\%) wykazało średni poziom poczucia osiągnięć osobistych, a wysoki poziom zaangażowania cechowało $20 \%$ badanych, tj. 30 osób. Niskim poziomem zaangażowania osobistego cechowało się 11 badanych $(7,3 \%)$. 
Niski poziom depersonalizacji wykazało $29,3 \%$ badanych, czyli 44 osoby. Największą grupę 64,7\% (97 osób) stanowili badani ze średnim poziomem depersonalizacji. Zaledwie 6\%, czyli 9 osób to pielęgniarki o wysokim poziomie depersonalizacji.

Analiza statystyczna nie wykazała istotnej zależności pomiędzy miejscem pracy badanych, a tym co dla nich było przyczyną stresu. Większość badanych bez względu na oddział na jakim pracowała główną przyczynę stresu upatrywała w przepracowaniu - personel oddziału dziecięcego, aż w 100\%, wewnętrznego i leczenia uzależnień w $80 \%$. Nadmiar obowiązków odczuwali również badani oddziału chirurgii ogólnej $(77,8 \%)$, onkologii $(75 \%)$, neurologii $(70 \%)$, nefrologii (50\%), chirurgii dziecięcej i okulistyki (57\%). Stresujący był również dla badanych brak finansów, w o/nefrologii i onkologii dla $25 \%$ badanych, w okulistyce i o/leczenia uzależnień dla $20 \%$ badanych, dla $14 \%$ badanych w oddziale chirurgii ogólnej i dziecięcej. Stres powodowały również konflikty w pracy, z którymi nie radziło sobie 16,7\% badanych w oddziale nefrologii, ok. 13-15\% badanych oddziału wewnętrznego, neurologii i okulistyki. Stresujące były również trudności w kontaktach z innymi, szczególnie dla badanych z oddziału okulistyki. Personel oddziałów wewnętrznego i neurologii podawał jako przyczynę stresu utrudnioną komunikację z pacjentem. Najwięcej badanych pracujących na oddziałach: wewnętrznym $(19,4 \%)$, neurologicznym $(20 \%)$ i onkologicznym (25\%) określało swoją pracę jako prawie zawsze stresującą. Natomiast badani z oddziału okulistycznego $21,4 \%$, z oddziału nefrologii ze stacją dializ 8,3\% uważali, że ich praca prawie nigdy nie jest stresująca. Około połowa badanych z oddziałów: neurologia (45\%), okulistyka (50\%), dziecięcy $(40 \%)$, chirurgia dziecięca $(57,1 \%)$ i onkologia $(41,7 \%)$ swoją pracę uważała za stresującą od czasu do czasu. Według badanych praca na oddziałach: leczenia uzależnień (50\%), nefrologii ze stacją dializ (33,3\%), wewnętrznym (29\%), neurologii (25\%) była często stresująca. Badani z oddziału chirurgii ogólnej mieli podzielone zdania, 29,6\% uważała, że ich praca często była stresująca, zaś 29,6\% uważała, że ich praca rzadko była stresująca. Często o zmianie zawo- 
du myśleli badani (20\%) pracujący w o/leczenia uzależnień, ok. 14\% personelu chirurgii ogólnej i dziecięcej również często rozważało zmianę zawodu. Duży odsetek badanych prawie nigdy nie brało pod uwagę zmiany zawodu: z o/dziecięcego $60 \%$, z okulistyki $50 \%$, z neurologii $35 \%$ badanych, z chirurgii ogólnej 44\%, z nefrologii 41\%, z wewnętrznego $38,7 \%, 30 \%$ badanych $\mathrm{z}$ o/leczenia uzależnień, $25 \% \mathrm{z}$ onkologii. Byli również badani, którzy rzadko myśleli o takiej ewentualności: z onkologii 50\% badanych, z chirurgii dziecięcej 35,7\% , 28,5\% z okulistyki, po $25 \%$ personelu nefrologii i neurologii również rzadko rozważało zmianę zawodu.

Analiza statystyczna wykazała istotną zależność pomiędzy miejscem pracy badanych a ich poziomem wypalenia zawodowego $\mathrm{w}$ wyczerpaniu emocjonalnym. Najwyższy poziom wyczerpania emocjonalnego wykazały pielęgniarki pracujące na oddziale neurologicznym z odcinkiem udarowym (27), wewnętrznym (25) chirurgii ogólnej (25), a najniższy poziom wyczerpania emocjonalnego cechował pielęgniarki pracujące na oddziale okulistycznym $(18,5)$.

Analiza statystyczna nie wykazała istotnej zależności pomiędzy miejscem pracy badanych, a ich poziomem wypalenia zawodowego w depersonalizacji. Objawy z podskali depersonalizacji dominowały u pielęgniarek/pielęgniarzy z oddziału neurologii $(14,3)$, a najmniej były widoczne u badanych z oddziału okulistyki $(10,7)$.

W podskali poczucia osiągnięć osobistych u wszystkich badanych występowało średnie nasilenie objawów w granicach 23,8.

Tabela 2. Ogólny wskaźnik wypalenia zawodowego.

\begin{tabular}{|l|c|c|}
\hline Ogólny wskaźnik wypalenia & Częstość & Procent \\
\hline poziom niski & 17 & 11,3 \\
\hline poziom średni & 127 & 84,7 \\
\hline poziom wysoki & 6 & 4 \\
\hline Ogółem & 150 & 100 \\
\hline
\end{tabular}

Źródło: Opracowanie własne na podstawie badań własnych. 
Badana grupa cechowała się średnim poziomem wypalenia $(84,7 \%)$. Wysoki poziom wypalenia wykazało $4 \%$ badanych, a niski poziom wypalenia $11,3 \%$ respondentów.

Tabela 3. Poziom wypalenia zawodowego a staż pracy.

\begin{tabular}{|c|c|c|c|c|c|c|c|c|}
\hline & \multicolumn{3}{|c|}{$\begin{array}{c}\text { Ogólny wskaźnik } \\
\text { wypalenia }\end{array}$} & \multirow{2}{*}{ Ogółem } & \multirow{2}{*}{$\begin{array}{l}\text { Chi-kwa- } \\
\text { drat } \\
\text { Pearsona }\end{array}$} & \multirow{2}{*}{$\mathbf{P}$} \\
\hline & & & $\begin{array}{c}\text { poziom } \\
\text { niski }\end{array}$ & $\begin{array}{l}\text { poziom } \\
\text { średni }\end{array}$ & $\begin{array}{l}\text { poziom } \\
\text { wysoki }\end{array}$ & & & \\
\hline \multirow{10}{*}{ 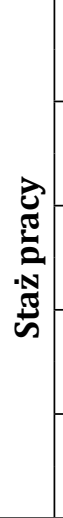 } & $0-10$ lat & $\mathrm{N}$ & 4 & 10 & 0 & 14 & \multirow{12}{*}{10,35} & \multirow{12}{*}{0,241} \\
\hline & - to lat & $\%$ & $28,6 \%$ & $71,4 \%$ & $0,0 \%$ & $100,0 \%$ & & \\
\hline & \multirow{2}{*}{$11-20$} & $\mathrm{~N}$ & 1 & 18 & 1 & 20 & & \\
\hline & & $\%$ & $5,0 \%$ & $90,0 \%$ & $5,0 \%$ & $100,0 \%$ & & \\
\hline & \multirow{2}{*}{$21-30$} & $\mathrm{~N}$ & 3 & 27 & 2 & 32 & & \\
\hline & & $\%$ & $9,4 \%$ & $84,4 \%$ & $6,3 \%$ & $100,0 \%$ & & \\
\hline & \multirow{2}{*}{$31-40$} & $\mathrm{n}$ & 6 & 65 & 3 & 74 & & \\
\hline & & $\%$ & $8,1 \%$ & $87,8 \%$ & $4,1 \%$ & $100,0 \%$ & & \\
\hline & \multirow{2}{*}{\begin{tabular}{|c|} 
powyżej \\
40
\end{tabular}} & $\mathrm{n}$ & 3 & 7 & 0 & 10 & & \\
\hline & & $\%$ & $30,0 \%$ & $70,0 \%$ & $0,0 \%$ & $100,0 \%$ & & \\
\hline \multirow{2}{*}{\multicolumn{2}{|c|}{ Ogółem }} & $\mathrm{n}$ & 17 & 127 & 6 & 150 & & \\
\hline & & $\%$ & $11,3 \%$ & $84,7 \%$ & $4,0 \%$ & $100,0 \%$ & & \\
\hline
\end{tabular}

Źródło: Opracowanie własne na podstawie badań własnych.

Wysoki poziom wypalenia występował $\mathrm{w}$ przedziale wiekowym 41-50 lat u 7,1\% badanych. Niski poziom wypalenia wykazali badani w wieku 20-30 lat, natomiast średni poziom wypalenia występował u większości badanych - w przedziale wiekowym $>50$ lat u $85,9 \%$ badanych, w przedziale 41-50 lat u 85,7\% badanych i w przedziale wieku 31-40 lat u 81,1\% badanych, a w mniejszym stopniu w przedziale 20 30 lat - 60\%. Większość badanych bez względu na staż pracy cechował średni poziom wypalenia zawodowego. Wysoki poziom wypalenia wystąpił u badanych ze stażem pracy 11-20 lat (5\%), 21-30 lat (6,3\%) i ze stażem 31-40 lat (4,1\%). Wysoki poziom wypalenia nie występował 
u pielęgniarek/pielęgniarzy rozpoczynających pracę i pielęgniarek emerytek, czynnych zawodowo. Najliczniejsza grupa pielęgniarek/pielęgniarzy również najmłodszych i najstarszych wykazała niski poziom wypalenia: 0-10 lat pracy $28,6 \%$ osób i ze stażem > 40 lat pracy $30 \%$ badanych.

Tabela 4. Poziom wypalenia zawodowego a miejsce pracy (oddział).

\begin{tabular}{|c|c|c|c|c|c|c|c|c|}
\hline & \multicolumn{3}{|c|}{$\begin{array}{c}\text { Ogólny wskaźnik } \\
\text { wypalenia }\end{array}$} & \multirow{2}{*}{ Ogółem } & \multirow{2}{*}{$\begin{array}{l}\text { Chi-kwa- } \\
\text { drat } \\
\text { Pearsona }\end{array}$} & \multirow{2}{*}{$\mathbf{P}$} \\
\hline & & & $\begin{array}{c}\text { poziom } \\
\text { niski }\end{array}$ & $\begin{array}{l}\text { poziom } \\
\text { średni }\end{array}$ & \begin{tabular}{|l|} 
poziom \\
wysoki \\
\end{tabular} & & & \\
\hline \multirow{18}{*}{ 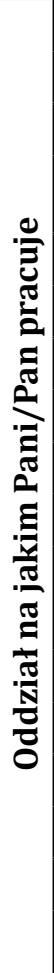 } & Whumetrrnu & $\mathrm{n}$ & 1 & 29 & 1 & 31 & \multirow{20}{*}{14,73} & \multirow{20}{*}{0,544} \\
\hline & vvewnęuzany & $\%$ & $3,2 \%$ & $93,5 \%$ & $3,2 \%$ & $100,0 \%$ & & \\
\hline & neurologia & $\mathrm{n}$ & 2 & 16 & 2 & 20 & & \\
\hline & $\begin{array}{c}\text { z oddziałem } \\
\text { udarowym }\end{array}$ & $\%$ & $10,0 \%$ & $80,0 \%$ & $10,0 \%$ & $100,0 \%$ & & \\
\hline & \multirow{2}{*}{ okulistyka } & $\mathrm{n}$ & 4 & 10 & 0 & 14 & & \\
\hline & & $\%$ & $28,6 \%$ & $71,4 \%$ & $0,0 \%$ & $100,0 \%$ & & \\
\hline & \multirow{2}{*}{ dziecięcy } & $\mathrm{n}$ & 1 & 9 & 0 & 10 & & \\
\hline & & $\%$ & $10,0 \%$ & $90,0 \%$ & $0,0 \%$ & $100,0 \%$ & & \\
\hline & \multirow{2}{*}{$\begin{array}{l}\text { O/ leczenia } \\
\text { uzależnień }\end{array}$} & $\mathrm{n}$ & 2 & 8 & 0 & 10 & & \\
\hline & & $\%$ & $20,0 \%$ & $80,0 \%$ & $0,0 \%$ & $100,0 \%$ & & \\
\hline & \multirow{2}{*}{$\begin{array}{l}\text { chirurgia } \\
\text { dziecięca }\end{array}$} & $\mathrm{n}$ & 2 & 12 & 0 & 14 & & \\
\hline & & $\%$ & $14,3 \%$ & $85,7 \%$ & $0,0 \%$ & $100,0 \%$ & & \\
\hline & \multirow{2}{*}{$\begin{array}{c}\text { chirurgia } \\
\text { ogólna }\end{array}$} & $\mathrm{n}$ & 3 & 22 & 2 & 27 & & \\
\hline & & $\%$ & $11,1 \%$ & $81,5 \%$ & $7,4 \%$ & $100,0 \%$ & & \\
\hline & \multirow{2}{*}{ onkologia } & $\mathrm{n}$ & 0 & 12 & 0 & 12 & & \\
\hline & & $\%$ & $0,0 \%$ & $100,0 \%$ & $0,0 \%$ & $100,0 \%$ & & \\
\hline & \multirow{2}{*}{$\begin{array}{c}\text { nefrologia } \\
\text { ze stacją } \\
\text { dializ } \\
\end{array}$} & $\mathrm{n}$ & 2 & 9 & 1 & 12 & & \\
\hline & & $\%$ & $16,7 \%$ & $75,0 \%$ & $8,3 \%$ & $100,0 \%$ & & \\
\hline & \multirow{2}{*}{ Ogółem } & $\mathrm{n}$ & 17 & 127 & 6 & 150 & & \\
\hline & & $\%$ & $11,3 \%$ & $84,7 \%$ & $4,0 \%$ & $100,0 \%$ & & \\
\hline
\end{tabular}

Źródło: Opracowanie własne na podstawie badań własnych. 
Większość badanych wykazała średni poziom wypalenia zawodowego: $100 \%$ badanych $\mathrm{z}$ onkologii, $93,5 \% \mathrm{z}$ oddziału wewnętrznego, $80 \%$ z neurologii, $90 \%$ z oddziału dziecięcego, $85 \%$ z oddziału chirurgii dziecięcej, $80 \%$ z o/ leczenia uzależnień, 81,5\% z chirurgii ogólnej, 75\% z nefrologii i $71 \%$ z okulistyki. Wysoki poziom wypalenia występował u $10 \%$ badanych z oddziału neurologii, 8,3\% oddziału nefrologii, u 7, 4\% z chirurgii ogólnej i 3,2\% z oddziału wewnętrznego. Wystąpili również badani wykazujący niski poziom wypalenia: aż 28,6\% stanowił personel okulistyki, $20 \%$ personel o/leczenia uzależnień, 16,7\% badanych z nefrologii, z chirurgii dziecięcej 14,3\%,11,1\% personelu chirurgii ogólnej i po 10\% z neurologii i dziecięcego. Znikomy odsetek pielęgniarek/pielęgniarzy (3,2\%) oddziału wewnętrznego również wykazywał niski poziom wypalenia. Wysoki poziom wypalenia zawodowego występował u pielęgniarek/pielęgniarzy, którzy postrzegali swoją pracę jako stresującą prawie zawsze $(21,1 \%)$. Natomiast większość badanych niezależnie od postrzegania swojej pracy za mniej lub bardziej stresującą wykazywała wypalenie zawodowe na poziomie średnim (84,7\%). Niski poziom wypalenia cechował pielęgniarki/ pielęgniarzy, którzy swoją pracę tylko rzadko lub prawie nigdy postrzegali jako stresującą - było to średnio 11,3\% badanych. Stresogenność pracy nie korelowała z poziomem wypalenia zawodowego (p-0,009).

Analiza statystyczna wykazała istotną zależność pomiędzy stresogennością pracy badanych, a ich poziomem wypalenia zawodowego w wyczerpaniu emocjonalnym. Pielęgniarki oceniające swoją pracę jako stresującą wykazywały wyższy poziom wyczerpania emocjonalnego. U badanych, którzy postrzegali swoją pracę jako często (26) lub prawie zawsze (28) stresującą dochodziło do wyczerpania emocjonalnego. Badani, którzy prawie nigdy nie postrzegali swojej pracy jako stresującej mieli niski poziom wyczerpania emocjonalne na poziomie 16,5.

Analiza statystyczna nie wykazała istotnej zależności pomiędzy stresogennością pracy badanych, a ich poziomem wypalenia zawodowego w depersonalizacji. Bez względu na to, czy swoją pracę postrzegali częściej, czy rzadziej za stresującą wykazali depersonalizację średnio na poziomie 12,8 . 
Im większe poczucie stresogenności swojej pracy tym wyższy poziom poczucia osiągnięć osobistych. U badanych, którzy uważali swoją pracę jako prawie stresującą wynosił on 28.

\section{Dyskusja}

W samocenie badanych większość pielęgniarek postrzegała swoją pracę jako stresującą, a głównym determinantem stresu było dla nich przepracowanie $(65,5 \%)$. Badania Kowalczuk[3] również potwierdzają, że $72 \%$ badanych pielęgniarek wykonując swoją pracę było narażonych na stres, podobnie badania Uchmanowicz [4], w których 64\% badanych pielęgniarek potwierdziło stres odczuwany w miejscu pracy. Wcześniejsze badania Płotki i innych[5] na grupie pielęgniarek psychiatrycznych, wykazują, że najbardziej stresujące czynniki to: zagrożenie bezpieczeństwa osobistego, mało widoczne efekty pracy i zły system wynagrodzeń. Stresujący charakter pracy pielęgniarek potwierdzają badania Nowakowskiej i innych[6], a jako główną przyczynę stresu wskazują na nadmiar obowiązków (68\%) i nadmierną liczbę pacjentów (55\%). Z badań własnych wynika, że najbardziej stresująca była praca na oddziale onkologicznym (42\%) i neurologicznym (45\%), ale pielęgniarki tam pracujące deklarowały przywiązane do zawodu i mimo ciężkości pracy w tych oddziałach, nie myślały o jego zmianie.

Z przeprowadzonych badań wynika, że większość pielęgniarek/ pielęgniarzy niezależnie od oddziału w jakim pracują, cechuje średni poziom wypalenia zawodowego. Autorzy badań nad wypaleniem podają, że rodzaj i specyfika oddziału mają wpływ na wypalenie zawodowe. Beisert [7] uważa, że najbardziej narażone są pielęgniarki pediatryczne, onkologiczne oraz psychiatryczne. Codzienna praca z nieuleczalnie chorymi, próba pomocy, która często kończy się niepowodzeniem, świadomość, że nie jest się w stanie pomóc choremu powoduje wyczerpanie, a w konsekwencji wypalenie. Z przeprowadzonych badań wynika, że najwyższy poziom wypalenia prezentują pielęgniarki w podskali wyczerpania emocjonalnego (48). Zadowalające jest to, że $20 \%$ badanych pielęgniarek/pielęgniarzy posiada również wysoki poziom poczucia 
osiągnięć osobistych, a tylko $6 \%$ badanych wykazuje wysoki poziom depersonalizacji. Wyniki badań Cipory i współ.[8] są podobne, wykazały najniższy wskaźnik wypalenia zawodowego w komponencie depersonalizacji, a wyższy w komponentach wyczerpania emocjonalnego i poczucia osiągnięć osobistych. W grupie przebadanej przez Dębską i współ.[9] w największym stopniu pielęgniarki wskazały na niskie poczucie własnej wartości, a co piąta odczuwała wyczerpanie emocjonalne. Najniższy poziom wypalenia uzyskano w podskali depersonalizacji, co może świadczyć o dobrym kontakcie pielęgniarka - pacjent.

\section{Wnioski}

U badanych stwierdzono średni poziom wypalenia zawodowego, a dominowały u nich objawy emocjonalnego wyczerpania. Zjawisko charakteryzowało szczególnie pracujących w oddziałach o dużym stopniu ciężkości. Stresujący charakter pracy badanych miał istotny wpływ na wystąpienie syndromu wypalenia zawodowego, był jego główną przyczyną, ale nie miał istotnego wpływu na decyzje dotyczące zmiany zawodu.

\section{Zalecenia dla praktyki pielęgniarskiej}

Ważnym elementem zapobiegania zjawisku są techniki, jakimi powinni posługiwać się pracownicy systemu ochrony zdrowia, aby skutecznie zdystansować się do występujących problemów. W zawodach medycznych obiektywizm i dystans emocjonalny uważa się za niezbędny warunek, umożliwiający zapewnienie pacjentowi dobrej opieki. Ta filozofia „zobiektywizowanej troski” łączy w sobie koncepcję troski o dobro pacjenta z ideą, że pewna osobista rezerwa wobec stresowych aspektów opieki nad pacjentem jest konieczna dla osiągnięcia tego celu. Brak posługiwania się tym procesem „zobiektywizowanej troski” sprawia, że całkowite wypalenie się staje się bardziej prawdopodobne. Pielęgniarki chroniąc się przed tym problemem powinny przyjąć aktywną postawę cechującą się obiektywną oceną miejsca pracy, unikaniem stresującej atmosfery, poszukiwaniem własnych sposobów bycia twórczym, przekonaniem, aktywnym słuchaniem, uczciwą oceną tego, co 
jest realne i rezygnacją z zamierzeń nierealnych. Sposoby zapobiegania syndromowi wypalenia są związane z umiejętnościami radzenia sobie ze stresem, z odpowiednimi warunkami pracy, umiejętnościami intra i interpersonalnymi oraz wsparciem społecznym.

\section{Bibliografia/ Bibliography:}

1. Beisert M. Przejawy, mechanizmy i przyczyny wypalania się pielęgniarek. [w:] Sęk H.(red.), Wypalenie zawodowe. Przyczyny i zapobiegania. Wydawnictwo Naukowe PWN, Warszawa 2004;182-183.

2. Stelcer B. Syndrom wypalenia zawodowego personelu medycznego. Przewodnik Menadżera Zdrowia. 2009, Nr 1.

3. Kowalczuk K. i wsp. Stres w pracy pielęgniarek jako czynnik ryzyka wypalenia zawodowego. Problemy Pielęgniarstwa. 2011;19(3):307-314.

4. Uchmanowicz I., Jankowska-Polańska B., Bronowicka G. Zjawisko wypalenia zawodowego wśród pielęgniarek pracujących na oddziałach onkologicznych - badania wstępne. Problemy Pielęgniarstwa. 2013; 21(4):476783.

5. Płotka A., Pitek A., Makara-Studzińska M. Stres a syndrom wypalenia zawodowego. Postępy Pielęgniarstwa i Promocji Zdrowia. 1999, Tom XV.

6. Nowakowska I., Rosińska R., Roszak K. Pielęgniarstwo-zawód szczególnie narażony na stres i wypalenie. Pielęgniarstwo Polskie 2017; 1(63):122.

7. Beisert M. Przejawy, mechanizmy i przyczyny wypalania się pielęgniarek. [w:] Sęk H.(red.), Wypalenie zawodowe. Przyczyny, mechanizmy, zapobieganie. Wydawnictwo PWN ,Warszawa 2009;201-203.

8. Cipora E., Smoleń E., Gazdowicz L., Maliwiecka T., Poźnik E. Poziom wypalenia zawodowego wśród pielęgniarek pracujących w publicznych zakładach opieki zdrowotnej. Problemy Pielęgniarstwa.2014;3 (22):254-255.

9. Dębska G., Cepuch G. Wypalenie zawodowe u pielęgniarek pracujących w zakładach podstawowej opieki medycznej. Problemy Pielęgniarstwa. 2008;16(3):273-275. 